\title{
Isolation of microflora in earthworms guts from different substrates
}

\author{
Mohamed Omer Albasha ${ }^{1}$, P. Gupta ${ }^{2}$, P. W. Ramteke ${ }^{2}$ \\ ${ }^{1}$ Department of Zoology, Alejelat Faculty of Science, Zawia University, Zawia, Libya \\ ${ }^{2}$ Department of Biological Science, Faculty of Science, Sam Higgingbottom Institute of Agricultural, Technology \& Science(SHIATS), \\ Allahabad, India
}

\section{Email address:}

Zaidmohd11470@gmail.com (M. O. Albasha)

\section{To cite this article:}

Mohamed Omer Albasha, P. Gupta, P. W. Ramteke. Isolation of Microflora in Earthworms Guts from Different Substrates. American Journal of Agriculture and Forestry. Vol. 2, No. 4, 2014, pp. 206-208. doi: 10.11648/j.ajaf.20140204.24

\begin{abstract}
The fungi and bacteria were analysed in the gut of Eudrilus eugeniae, from different feed substrates like dry leaves, plastic waste, kitchen waste and waste paper. Certain species of fungi (Saksenae vasiformis, Mucor plumbeus, Cladosporium carrionii, C. herbacium, Alternaria sp., Cunninghamella echinulata, Mycetia sterila, Syncephalostrum racemosum, Curvalaria lunata, C. geniculata and Geotrichum candidum) and bacteria (Pseudomonas aeruginosa, Mima polymorpha, E. cloacae, Proteus vulgaris, P. mirabilis, P. rettgeri, Escherichia coli, Staphylococus citreus, B. cereus, Enterococci and Micrococci) were completely digested. Certain other species were not digested fungi like Aspergillus fumigatus, A. flavus, The microbial proliferation was more in the casts, due to the environment prevailing - rich in nutrient supply and large surface area available for growth and reproduction of the microbes that lead to enhanced microbial activity and humic acid contents in the casts.
\end{abstract}

Keywords: Microflora, Earthworm gut, Microbial Population, Dry Leaves, Plastic Waste, Kitchen Waste and Waste Paper

\section{Introduction}

Earthworms are very important soil creatures as they make up a large portion of the total biomass of invertebrates of the soil. Though earthworms are well studied organisms all over the world. The work on their taxonomy is far beyond completion. More than 3000 species of earthworms are known. In one hectare of soil, rich in organic matter and good moisture content, one can expect a population of 50,000 to 400,000 earthworms which are able to produce 25-30 tones of castings. Earthworms are hermaphrodites and they can double their population in one month in ideal conditions of temperature, moisture and food i.e. organic matter.

The present study was aimed at studying the different aspects of the symbiotic relationship between the microbes found in the four different substrates such as dry leaves, plastic waste, kitchen waste and waste paper and species of earthworms - Eudrilus eugeniae (Eudrilidae), and to find whether some of these microbes are commonly found in these feed and whether there is a common requirement of microbes as feed for earthworms at knowing gut microflora of earthworms in the fields of Sam Higgingbottom Institute of Agricultural Technology \& Science(SHIATS), Allahabad, India.

\section{Materials and Methods}

\subsection{Collection of Organic Wastes and Earth Worm Culture}

Collection of earthworm culture on different substrates like dry leaves, plastic waste, kitchen waste and waste paper were made from the Department of Biological Science of SHIATS and were used as feed substrates for adult earthworms.

Eudrilus eugeniae, 50 worms were maintained in separate Brick bed containers $(50 \times 35 \times 35 \mathrm{~cm})$ containing $5 \mathrm{~kg}$ of feed material at $28 \pm 2{ }^{\circ} \mathrm{C}, 75 \%$ moisture, $70 \% \mathrm{RH}$. The feed was not changed during the experiment lasting for 90 days. The worms were acclimatized for 2 days in the feed substrate before the commencement of the experiment. Microbial analysis was done on vermicasts collected 
after15 days of commencement of experiment.

Earthworms (E. eugeniae) collected from the vermicom posting unit of our college, were washed with sterilized tap water and placed on sterile Petri plate with moistened filter paper for 24 hours. They were then cleaned externally with $70 \%$ ethanol and dissected, weighed and homogenized for 15 minutes with avortex mixture in sterile $0.85 \% \mathrm{NaCl}$ solution.

Isolation of microflora was done by dilution plate method. For this, the mid gut of the earthworm was excised and the gut content (1g) was suspended in $10 \mathrm{ml}$ of sterile $0.85 \% \mathrm{NaCl}$ solution, serially diluted $\left(10^{-1}\right.$ to $\left.10^{-7}\right)$. After serial dilution $0.1 \mathrm{ml}$ solution was taken using sterile micropipette and plated sugar as on nutrient agar medium. The plates were then incubated sample at $28^{\circ} \mathrm{C}$ for 24 hours. Three replicates were maintained from each dilution.

\subsection{Isolation, Enumeration and Identification of Microflora}

The population of fungi and bacteria, from the substrates (dry leaves, plastic waste, kitchen waste and waste paper) was determined by dilution plate techniques [1]. Each substrate of $1 \mathrm{gm}$ was suspended in $1 \mathrm{ml}$ sterile saline $(1 \mathrm{~g}$ $\mathrm{NaCl}$ in $100 \mathrm{ml}$ distilled $\mathrm{H}_{2} \mathrm{O}$ ) in a sterile test tube and was shaken thoroughly in a mixer and used as inoculum for isolation and enumeration of fungi and bacteria from different substrates. Using micropipette, $0.01 \mathrm{ml}$ of the inoculum was inoculated into Nutrient agar (NA) [2], plates and spread over each plate media by using platinum loop for bacterial growth, Potato dextrose agar (PDA) plates for fungi and incubated at $28^{\circ} \mathrm{C}$ for 48 hours for bacteria, and $28^{\circ} \mathrm{C}$ for 7 days for fungi, respectively. The different colony forming units (CFU) developing on the media were estimated and expressed as CFU.

To identify the bacteria, Gram's staining tests were carried out as described by Mahon and Manuselis [3]. In addition to these, the current taxonomic sources were used in identification procedure. To identify the fungi, light microscopic examination was carried out in the Lactophenol cotton blue stained slides of each developed colonies in the Petri dish and also cultural characteristics such as colour of the fungal colony, number of days taken for the fungus to reach maximum diameter $(9 \mathrm{~cm})$ of the Petri dish, and the texture of fungal growth were noted. The morphological and cultural features of each fungus were compared with descriptions given by Kwon Chung and Bennett [4] for identification.

\subsection{Statistical Analysis}

The values were presented as means of different groups. Differences between the mean values were estimated using one way ANOVA. The results were considered statistically significant when $\mathrm{p}<0.05$.

\section{Results and Discussion}

The diversity of types and number of fungi and bacteria isolated from the gut of E. eugeniae as influenced by different feed substrates like dry leaves, plastic waste, kitchen waste and waste paper are tabulated in table 1 , and figures $1 \& 2$. Of the four substrates, it was observed, that kitchen waste harbours the maximum variety and number of fungi and bacteria followed by dry leaves. The least diversity of microflora was found in control then plastic waste.

Table 1. Isolation of microbes in the gut of earth worms reared in different substrates.

\begin{tabular}{|c|c|c|c|c|c|}
\hline \multirow{2}{*}{ Microbes } & \multicolumn{5}{|l|}{ Substrate } \\
\hline & Dry leaves & Plastic waste & kitchen waste & waste paper & Control \\
\hline \multicolumn{6}{|l|}{ Fungi (CFU x $\left.10^{6} \mathrm{~g}^{-1}\right)$} \\
\hline Aspergillus fumigatus & $32^{*}$ & 12 & $35^{*}$ & $28^{*}$ & 9 \\
\hline Aspergillusflavus & $21^{*}$ & $17^{*}$ & $32^{*}$ & $22^{*}$ & 1 \\
\hline Rhizopus sp. & $24^{*}$ & $10^{*}$ & $25^{*}$ & $11^{*}$ & 5 \\
\hline Total & $77^{*}$ & $39^{*}$ & $92^{*}$ & $61^{*}$ & 15 \\
\hline \multicolumn{6}{|l|}{ Bacteria (CFU x $\left.10^{6} \mathrm{~g}^{-1}\right)$} \\
\hline \multicolumn{6}{|l|}{$\mathrm{G}-\mathrm{ve}$} \\
\hline Pseudomonas aeruginosa & 2 & 1 & $5^{*}$ & 3 & 1 \\
\hline Bacterium antitratum & 0 & 0 & $7^{*}$ & 2 & 2 \\
\hline Enterobactera erogenes & $28^{*}$ & 14 & $29^{*}$ & 17 & 17 \\
\hline \multicolumn{6}{|l|}{$\mathrm{G}+\mathrm{ve}$} \\
\hline Bacillus subtilis & 3 & 1 & 5 & 1 & 1 \\
\hline Total & $33^{*}$ & 16 & $46^{*}$ & 23 & 21 \\
\hline
\end{tabular}

*: Significant differences as compared with control group ( $\mathrm{P}<0.05$ ).

Earthworms, for their growth and reproduction, have been shown to meet their essential nutritional requirement by feeding on organic matter and microbes [5]. Edwards and Fletcher [6] concluded that fungi were the major sources of nutrients for earthworms and that bacteria were of minor nutritional importance and soil algae were of moderate importance.
A significant increase of microbial populations $(p<0.05)$ in the guts of earthworm reared on different substrates was observed in the present study particularly fungi as well as bacteria - A. fumigatus, A. flavus, Rhizopus sp. Pseudomonas aeruginosa, Bacterium antitratum, Enterobacter aerogenes, Bacillus subtilis. Similarly increased population of fungi like A. flavus, A. fumigatus 
[7,8], and bacteria like B. idozus and B. cereus [9] were reported in the casts.

In the present study, more amylolytic (Aspergillus sp., Rhizopus sp. and Bacillus sp.), cellulolytic (Aspergillus sp., Bacillus sp. and Pseudomonas sp.), proteolytic (Aspergillus sp. and Bacillus sp.), phosphate solubilizing (Pseudomonas $s p$., Bacillus sp. and Aspergillus sp.) and nitrifying (Aspergillus flavus, Pseudomonas sp., Enterobacter sp. and Bacillus sp.) microbes were found significantly in the gut of the earth worm.

The role of microbes and earthworms in decomposition of organic matter and particularly, in humification is well known $[10,11]$. Humification has been shown to be, predominantly, a microbial process [12-14] and recently earthworms, E. eugeniae have been shown to aid in humification [15]. In the present study, there is a direct correlation between the microbial population activity and humic acid content in the earthworm guts. With the increase in microbial population there is an increase of microbial activity and humic acid content.

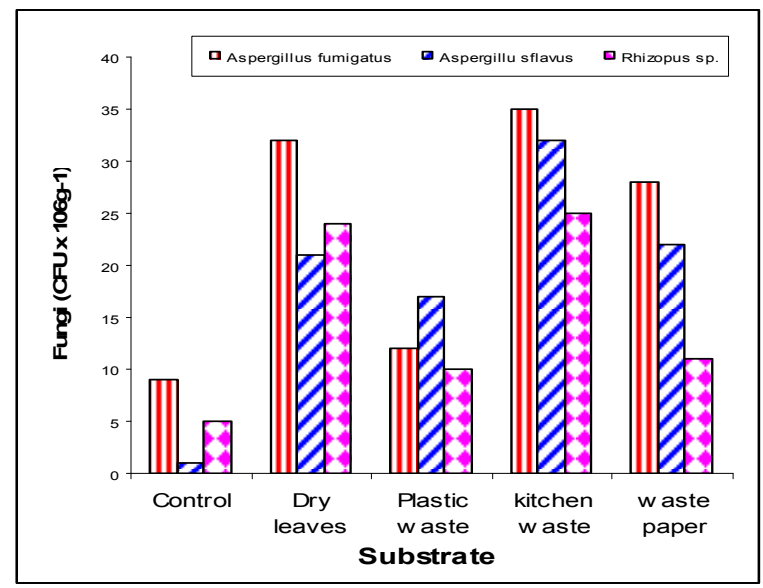

Figure 1. Isolation of fungi in the gut of earth worms reared in different substrates.

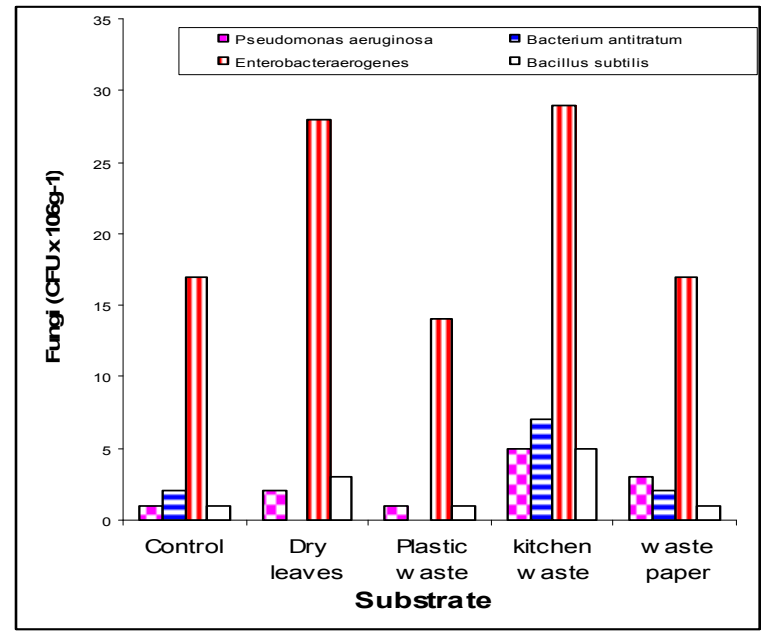

Figure 2. Isolation of bacteria in the gut of earth worms reared in different substrates.

\section{References}

[1] Walksman, S.A.: Is there any fungus flora in the soil? Soil Sci., 3: 565-589 (1917).

[2] Anonymous, A.: Difco manual of dehydrated culture media and reagent for microbiological and Clinical Laboratories. Inc. Detroit. Michigan, 1977, pp.350.

[3] Mahon, R.C. and Manuselis, J.R.: Utilization of colonial morphology for the presumptive identification of microorganisms In: Text book of Diagnostic Microbiology (Eds: Mahon, R.C. and Manuselis, J.R.). W.B. Saunders Company, Pennsylvania,1995, pp. 307-321.

[4] Kwon Chung, J.K. and Bennett, E.J.: Laboratory diagnosis. In: Medical mycology., Chap 3. pp. 44-71. Lea \& Febiger, Philadelphia, London, 1992.

[5] Parthasarathi, K. and Ranganathan, L.S.: Influence of press mud on the development of the ovary, oogenesis and the neurosecretory cells of the earthworm, Eudrilus engeniae (Kinberg). African Zool., 2000;35(2): 281-286.

[6] Edwards, C.A and Fletcher, K.E.: Interaction between earthworms and microorganisms in organic matter breakdown. Agri. Ecosyst. Environ., 1988;24: 235-247.

[7] Dash, H.K., Beura, B.N. and Dash, M.C.: Gut load, transit time, gut microflora and turnover of soil, plant and fungal material by some tropical earthworms. Pedobiologia, 1986;29: 13-20.

[8] Ghosh, N., Basu, S. and Behera, N.: Microfungi in the gut and cast of Perionyx millardi, a tropical earthworm. J. Soil Biol. Ecol., 1989; 9(1): 46-50.

[9] Kozlovskaya, L.S. and Zhdannikova, E.N.: Joint action of earthworms and microflora in forest soils. Dokl. Akad. Nauk SSSR, 1961;139: 470- 473.

[10] Edwards, C.A. and Bohlen, P.J.: Biology and ecology of earthworms, $3^{\text {rd }}$ Ed., Chapman and Hall, London, 1996.

[11] Cai, H., Zarda, B., Mattison, R.G., Schonholzer, F. and Hahn, D.: Fate of protozoa transiting the digestive tract of the earthworm Lumbricus terrestris L. Pedobiologia, 2002;46:161-175.

[12] Stevenson, F.J.: Humus chemistry. Genesis, composition and reactions, John Wiley and Sons Incorporation, New York, 1994.

[13] Filip, Z., Pecher, W. and Berthelin, J.: Microbial utilization and transformation of humic acids extracted from different soils. J. Plant Nutri. Soil Sci., 1999;162: 215-222 .

[14] Rovira, S.P.A., Brunetti, G., Polo, P. and Senesi, N.: Comparative chemical and spectroscopic characterization of humic acids from sewage sludges and sludge amended soils. Soil Sci., 2002;167(4): 235-245.

[15] Manivannan, S., Ramamoorthy, P., Parthasarathi, K. and Ranganathan, L.S.: Effect of sugar industrial wastes on the growth and reproduction of earthworms. India J. Exp. Zool., 2004;7(1): 29-37. 